\title{
PEMBINAAN DAN PENDANPINGAN REMAJA KICK BOXING GUNA MENCEGAH PRILAKU PENYALAHGUNAAN NARKOBA
}

\author{
Indah Kusuma Dewi \\ Fakultas Hukum Universitas Muhammadiyah Buton \\ e-mail: indahkusumamh@gmail.com
}

\begin{abstract}
ABSTRAK
Tujuan dari kegiatan pengabdian kepada masyarakat kali ini adalah untuk menganalisis bentuk pembinaan dan pendampingan remaja kick boxing guna mencegah prilaku penyalahgunaan narkoba di Kota Baubau. Kesimpulan yang diperoleh dari kegiatan Pengabdian Kepada Masyarakat adalah: 1) Bentuk pembinaan yang diberikan kepada remaja agar tidak menyalahgunakan narkoba adalah: a) dengan merubah sikap dan tingkah laku remaja yang negatif ke sikap yang positif, misalnya yang tadinya tidak rajin sholat tepat pada waktunya diajarkan untuk disiplin yaitu sholat tepat pada waktunya, atau yang membawa kendaraan bermotor yang tidak memiliki sim hendaknya yang sudah cukup umur mengurus sim atau yang belum cukup umur jangan membawa motor; b) dilatih mengendalikan emosionalnya misalnya jangan suka memaki kepada siapa saja; c) usaha penggemblengan mental intelektual dengan melihat segala potensi yang dimiliki dalam hal ini menyangkut kelebihan dan kekurangannya; d) Diajarkan tentang hidup sebagai makhluk sosial dan e) pembentukan identitas diri; 2).Bentuk pendampingan yang dilakukan dalam Pengabdian Kepada Masyarakat (PPM) ini adalah dengan 3 (tiga) pendekatan yaitu: a) orang tua; b) para guru di sekolah termasuk guru mengaji dan c) pelatih kick boxing.
\end{abstract}

Kata Kunci: pembinaan, pendampingan remaja, penyalahgunaan narkoba

\section{A. PENDahuluan}

Masuknya budaya asing ke Indonesia mengakibatkan pula beraneka ragam peristiwa diantaranya adalah masalah narkotika. Masalah narkotika di Indonesia dewasa ini merupakan masalah yang aktual, disamping masalahmasalah sosial lainnya, karena narkotika merupakan masalah yang sudah menjadi pembicaraan dan perhatian masyarakat luas. Penyalahgunaan narkotika merupakan bahaya yang sangat memprihatinkan, karena narkotika dapat merusak pribadi-pribadi yang menyalahgunakannya, baik secara fisik maupun mental.

Penyalahgunaan dan peredaran narkotika secara illegal sangat merugikan perorangan maupun masyarakat luas khususnya generasi muda, bahkan dapat 
menimbulkan bahaya yang lebih besar bagi kehidupan dan nilai-nilai budaya bangsa yang pada akhirnya akan dapat melemahkan ketahanan nasional. Bahkan tindak pidana narkotika yang bersifat transnasional pada umumnya dilakukan dengan menggunakan modus operandi dan sarana teknologi modern. Perkembangan tindak pidana narkotika tersebut sudah menjadi ancaman yang sangat serius bagi kehidupan setiap bangsa dan ummat manusia pada umumnya.

Dampak semakin meningkatnya jumlah pecandunya maka akan mengakibatkan terjadinya gangguan terhadap keamanan dan ketertiban masyarakat yaitu dari meningkatnya kriminalitas sampai pada penyakit sosial lainnya. Umumnya remaja tidak mengetahui akan akibat yang ditimbulkannya dari penyalahgunaan narkotika. Mereka hanya mengetahui bahwa dengan menggunakan narkotika akan mendapatkan rasa nikmat dengan mengkhayal dalam perasaan menyenangkan.

Kata Narkotika berasal dari bahasa Yunani narkotikos yang artinya dalam bahasa medis adalah letbargy, yaitu seseorang yang berada dalam keadaan lesu, lemah, letih dan kelelahan. Secara umum pengertian narkotika adalah suatu zat yang dapat menimbulkan terjadinya perubahan perasaan, penalaran dan pengamatan, karena zat tersebut berpengaruh terhadap system saraf pusat (Darmono, 2006: 22).

Kata narkotika berasal dari bahasa Inggris yaitu narcotics yang berarti obat bius. Dalam bahasa Yunani disebut dengan narkose, yang berarti menidurkan atau membius.Definisi narkotika adalah zat atau obat, baik yang berasal dari tanaman, sintetis, maupun semi sintetis, yang dapat menyebabkan penurunan atau perubahan kesadaran, hilangnya rasa, mengurangi sampai enghilangkan rasa nyeri, dan dapat menimbulkan ketergantungan.Secara umum, narkotika mempunyai kemampuan menurunkan dan mengubah kesadaran (analgetik). Di dunia pengobatan, senyawa ini biasa digunakan sebagai obat bius (anestetika) yang dipakai untuk membius orang yang akan dioperasi sehingga tidak merasakan sakit sewaktu operasi berlangsung. Selain itu narkoti juga digunakan untuk obat penekan batuk (antitusiva) dan obat penekan rasa nyeri (analgetika) (Ida Listyarini Handoyo, 2004: 1). 
AR.Sujono dan Bony Daniel (2011: 59) menyatakan bahwa narkotika merupakan zat atau obat yang sangat bermanfaat dan diperlukan untuk pengobatan penyakit tertentu dan untuk kepentingan ilmu pengetahuan. Namun jika disalahgunakan atau digunakan tidak sesuai dengan standar pengobatan dapat menimbulkan akibat yang sangat merugikan bagi perseorangan atau masyarakat khususnya generasi muda. Hal ini akan lebih merugikan jika disertai dengan penyalahgunaan dan peredaran gelap narkotika yang dapat mengakibatkan bahaya yang lebih besar bagi kehidupan dan nilai-nilai budaya bangsa yang pada akhirnya akan dapat melemahkan ketahanan nasional.

Narkoba atau napza adalah obat, bahan, dan zat yang jika diminum, dihisap, dihirup, ditelan, atau disuntikan berpengaruh pada keja otak dan sering menyebabkan ketergantungan, akibatnya kerja otak berubah (meningkat atau menurun). Demikian pula dengan fungsi vital organ tubuh lain, seperti jantung, peredaran darah, pernafasan (Martono, Lydia Harlina dan Satya Joewana, 2006: 5).

Narkotika dalah zat atau obat yang berasal dari tanaman atau bukan tanaman, baik sintesis maupun semi sintesis yang dapat menyebabkan sintesis penurunan atau perubahan kesadaran, menghilangkan atau mengurangi rasa nyeri (Martono, Lydia Harlina dan Satya Joewana, 2006: 6).

Psikotropika adalah zat atau obat, baik alamiah maupun sintesis bahan narkotika, yang berkhasiat psikoaktif melalui selektif pada susunan saraf pusat dan perubahan khas pada aktifitas-aktifitas mental dan prilaku, serta menyebabkan ketergantungan (Martono, Lydia Harlina dan Satya Joewana, 2009: 7).

Kecanduan adalah kondisi dimana penderita tergantung pada dosis berulang kali pada obat, dan akan menggunakan dosis yag makin besar bahkan akan pindah keobat yang lebih berbahaya. Tiga karakteristik utama dari kecanduan obat adalah menggunakan obat dalam jumlah besar. Tidak berhasil menggunakan obat, dan gejala kemundurun (Tho Lai Hong dan Ho Peck Leng, 2001: 275).

Berdasarkan Undang-Undang Nomor 35 Tahun 2009 tentang Narkotika Pasal 1 angka 15 pengertian penyalah guna adalah Orang yang menggunakan 
narkotika tanpa hak atau melawan hukum. Pasal 1 angka 6 Undang-Undang No. 35 Tahun 2009 tentang Narkotika menyebutkan bahwa peredaran gelap narkotika dan prekursor narkotika adalah setiap kegiatan atau serangkaian kegiatan yang dilakukan secara tanpa hak atau melawan hukum yang ditetapkan sebagai tindak pidana narkotika dan prekursor narkotika.

Harmawati (2013: 23) menyatakan bahwa pencegahan adalah kegiatan penyuluhan dan bimbingan untuk memberikan penerangan dan pengetahuan kepada masyarakat yang rawan menyalahgunakan Narkoba dan untuk membangkitkan kesadaran mereka tentang bahaya penyalahgunaan narkoba (suatu kondisi dimana seseorang menggunakan narkoba yang tidak untuk tujuan pengobatan atau yang digunakan tanpa mengikuti petunjuk atau dosis yang diberikan dokter).

Menurut Victor Pudjiadi (2013: 53) bahwa usaha pencegahan penyalahgunaan serta peredaran gelap Narkoba penting terus dikampanyekan guna melindungi masyarakat serta generasi muda dari ancaman keterpurukan atau hilangnya generasi muda yang berkualitas. Ibarat meja yang "growak" akibat rayap, maka sama halnya dengan otak yang terkena Narkoba, akan rusak dan tidak bisa diperbaiki lagi.

Usia muda (remaja) merupakan usia produktif yang membutuhkan perhatian khusus, karena pada posisi ini, taraf pencarian jati diri dan cenderung masih bersifat labil. Pola pikir kaum muda kadang kala hanya bersifat instan, dan mencari yang temudah mana kala menghadapi sesuatu yang sulit. Ada beberapa faktor sebagai penyebab atau yang mempengaruhi perilaku seorang remaja, diantaranya:

a. Faktor Pertemanan

b. Perkembangan Teknologi Informasi

c. Pengaruh Budaya

d. Gaya Hidup Hedonism

Beberapa faktor itulah sebagai pemicu dalam setiap pola hidup maupun dasar pemikiran seseorang, termasuk dalam hal penyalahgunaan narkoba. seringkali seorang anak muda terjebak kedalam lembah hitam narkoba hanya karena faktor pertemanan sehingga memunculkan keinginan coba-coba. Kalau kita analisa 
pengaruh teman sebaya menjadi metode paling ampuh untuk urusan peredaran gelap narkoba. Seseorang begitu mudah terpengaruh oleh teman yang dianggap selevel. Selain itu perkembangan teknologi yang semakin canggih, dari sisi negatifnya juga memunculkan potensi-potensi negatif pula. Pada masa seperti saat ini adalah boleh dibilang The Nations Without State, arus informasi begitu deras masuk tanpa melalui filter sehingga batas pergaulan boleh di bilang bebas tanpa batas (Anwar Nuris, 2013: 23).

Tindak pidana Narkoba di Indonesia diatur dalam Undang-Undang Nomor 35 Tahun 2009 Tentang Narkotika. Dalam Undang-undang tersebut diatur secara rinci berkaitan sangsi pidana maupun proses hukum dari para pelaku. Hal ini merupakan wujud penyempurnaan dari Undang-udang tahun 1997 tentang Psikotropika. Undang-Undang Nomor 35 bukti keseriusan negara dalam upaya pemberantasan Narkoba. Tindak pidana Narkoba merupakan Lect Specialist atau pengkhususan jika dibanding dengan tindak pidana lainnya. Dalam Undangundang tersebut sangsi terberat adalah hukuman mati dengan berbagai pertimbangan tertentu. Yang menjadi harapan besar adalah memberlakukan aturan perundangan dengan sebenarnya untuk mampu menekan tingkat penyalahgunaan Narkoba di Indonesia tercinta. Dalam pasal 54 Undang-Undang Nomor 35 tahun 2009 dijelaskan bagi para pecandu/penguna wajib menjalani rehabilitasi baik medis maupun sosial, tentunya dengan memperhatikan berbagai prasyarat yang ada. Selain upaya penegakan hukum dan rehabilitasi, diperlukan partisipasi aktif dari segenap lapisan masyarakat untuk turut mendukung upaya penangulangan narkoba, sebagaimana diatur dalam pasal 104 Undang-Undang Nomor 35 tahun 2009. Dalam pasal tersebut dijamin keterlibatan masyarakat dalam memberikan informasi untuk masalah tindak pidana Narkotika. Sebuah harapan besar termaksud dalam amanat Undang-undang ini dalam menghambat peredaran gelap narkoba di bumi tercinta.

Kick Boxing di Kota Baubau dibentuk pertama kali tanggal 21 Juli 2018, dimana yang tergabung di dalamnya banyak yang berkategori usia remaja karena berusia 16-20 tahun sebanyak 22 orang dan 10 orang berkategori anak yaitu berusia 7-12 tahun. Kondisi ini tentunya memerlukan perhatian yang serius, 
apalagi pengedaran narkoba di Sulawesi Tenggara maupun Kota Baubau cukup merisaukan, apalagi targetnya adalah para remaja, sebagaimana diberitakan dalam koran indopos yaitu Kota Baubau masuk sebagai salah satu zona merah peredaran kasus Narkoba di Sulawesi Tenggara. Posisinya yang strategis menjadi gerbang paling nyaman bagi pengedar yang membawa masuk barang haram itu baik dari jalur udara maupun melalui jalur laut. Berdasarkan raport kasus narkoba yang diungkap Satnarkoba Polres Baubau, sepanjang tahun 2015 terdapat sedikitnya delapan kasus narkoba. Jumlah tersebut meningkat dari perolehan tahun sebelumnya yang hanya enam kasus dengan 14 tersangka, kata Kasat Narkoba Polres Baubau, AKP Anwar MH. Katanya, bukan hanya narkoba, peredaran obat somadril alias mumbul juga mulai marak di Baubau. Dari catatan 2015 kasus pengedar obat mumbul tanpa izin yang ditangani Polres Baubau menyeret 12 tersangka. "Kasus penggunaan obat mumbul ini menjadi salah satu perhatian mengingat sudah sangat marak digunakan kalangan pelajar," tambahnya. Para tersangka yang terjerat dalam kasus peredaran maupun pengguna narkoba di Baubau memiliki latar belakang yang bermacam-macam. Selain wanita yang bekerja di THM, Polres Baubau juga pernah mengamankan anggota polisi yang ikut terjerat dalam pusaran kasus narkoba. Terbaru, akhir pekan lalu polisi sempat mengamankan salah seorang wanita berumur 27 tahun dalam sebuah operasi penggerebekan di Kelurahan Bukit Wolio Indah. Di dalam kamar kos tersangka yang dikenal bernama Cici Aprilliyah Matius, polisi berhasil menemukan barang bukti berupa narkotika jenis sabu dengan berat 0,30 gram dan alat isap alias bong. Tersangka kini telah diamankan di Satnarkoba Polres Baubau untuk dilakukan pemeriksaan dan pengembangan. Cici diduga kuat merupakan pengguna dan juga terlibat dalam jaringan peredaran narkoba di Baub au. "Sindikatnya masih dalam penyelidikan dan pengembangan tim penyidik. Diprediksi tahun 2016 potensi peredaran barang haram itu di Baubau masih terus berkembang. Kendati demikian polisi berharap dengan berbagai upaya yang dilakukan termasuk pencegahan dan penangkapan terhadap pelaku pengedar dan pengguna bisa menekan peredaran narkoba di Kota Baubau http://www.indopos.co.id/2015/12/peredaran-narkoba-dibaubau-meningkat.html\#sthash.uOVExyUx.dpuf 
Berdasarkan analisis tersebut, maka rumusan permasalahan dari kegiatan pengabdian kepada masyarakat kali ini adalah bagaimana bentuk pembinaan dan pendampingan remaja kick boxing guna mencegah prilaku penyalahgunaan narkoba di Kota Baubau.

\section{B. METODE}

Kegiatan pengabdian kepada masyarakat (PPM) kali ini dengan menggunakan metode pembinaan dan pendampingan kepada remaja yang mengikuti olah raga kick boxing pada pengurus Kota Baubau sebanyak 22 orang. Pembinaan yang dimaksud dini adalah dengan memberikan pengetahuan atau pengenalan awal terhadap jenis-jenis narkoba dan bahayanya jika dikonsumsi, apalagi digunakan terus menerus tentunya akan berakibat maut bagi yang menggunakannya. Pendampingan yang dimaksud adalah karena usia remaja itu merupakan usia yang membutuhkan perhatian yang sangat serius, agartidak terjebak dengan hal-hal yang negatif, maka pendampingan perlu terus menerus dilaksanakan tidak hanya pada saat proses pengabdian kepada masyarakat, tetapi juga diharapkan pada saat latihan direkomendasikan untuk dilaksanakan pesanpesan moral salah satunya menyangkut masalah narkoba, agar remaja tidak terjebak dengan masalah tersebut, oleh karena para pelatih kick boxing perlu tanggap dengan permasalahan ini. dengan mengajak remaja kick boxing, agar selalu mengisi kehidupan mereka dengan hal-hal yang positif dan jika terdapat permasalahan seharusnya dapat dikomunikasikan dengan keluarga, maupun orang-orang yang terdekat dengan para remaja tersebut yang tentunya dipercaya mengajarkan hal-hal yang positif berupa pesan-pesan moral seperti guru di sekolah, guru mengaji, pelatih kick boxing.

Kegiatan pengabdian kepada masyarakat ini dilaksanakan selama 3 (tiga) bulan November 2018 sampai Januari 2019 bertempat di Latihan Kick Boxing Kota Baubau yaitu Aula kantor Dewan Perwakilan Rakyat Daerah (DPRD) Kota Baubau.

\section{HASIL DAN PEMBAHASAN}

Pengabdian Kepada Masyarakat (PPM) terlebih dahulu diawali melakukan proses surat menyurat dengan Pengurus Cabang Kick Boxing 
Indonesia (KBI) Kota Baubau, karena latihan yang dilakukan sesuai dengan opservasi awal yaitu 2 kali seminggu, yaitu hari Kamis dan Minggu, dan pada hari Minggu semua lengkap datang latihan menurut wawancara dengan salah satu pelatihnya yaitu Dorajatun Andara, maka saya meminta untuk mengisi pada setiap hari Minggu, selama 3 bulan, sehingga total seluruhnya 12 kali pertemuan dan kami menggunakan hanya 1 jam dari 2 jam latihan setiap pertemuan

Dari 22 (dua pulu dua) orang remaja Kick Boxing yang ada di Kota Baubau, semuanya (100\%) belum mengetahui tentang jenis-jenis narkoba, namun bahayanya terhadap kelangsungan hidup mereka, sudah mereka kenali. Mereka merasa bimgung dengan penegakan hukum yang ada yang tidak konsisten dari respon yang mereka berikan terutama pada pemakai, mengapa ada yang direhabilitas dan ada yang dipidanakan?, atau mereka mempertanyakan mengapa begitu mudahnya barang-barang ini beredar di Indonesia tanpa adanya pengawasan yang jelas dari aparat yang berwenang?, atau ada yang bertanya bagaimana seharusnya memilih teman agar terhindar dari penyalahgunaan narkoba? Serta bagaimana perlindungan Negara terhadap bahaya narkoba?

Gambar berikut merupakan lambang Pengurus Cabang Kick Boxing Indonesia (KBI) Kota Baubau

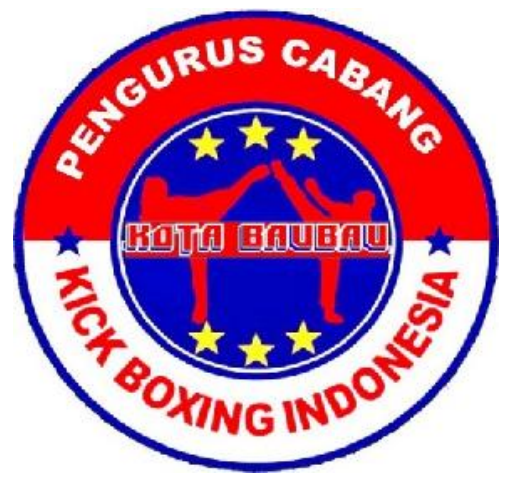

Gambar 1;

Lambang Pengurus Cabang Kick Boxing Indonesia (KBI) Kota Baubau

Berdasarkan hasil diskusi dengan para remaja Kick Boxing Kota Baubau, maka kita dapat mengetahui dan merumuskan faktor-faktor yang menjadi penyebab penyalahgunaan narkoba di kalangan remaja adalah:

1. Karakteristik psikologis yang khas pada remaja, faktor ini akibat para remaja tertekan dan tidak mampu mengatasi berbagai masalah yang timbul sehingga 
menimbulkan stress dan biasanya banyak terjadi pada remaja yang tidak memiliki kemampuan dalam mengkomunikasikan segala permasalahan yang timbul dan biasanya di pendam sendiri apalagi suka menyendiri dan pada akhirnya ditunjang dengan pengetahuan yang minim terhadap zat-zat tersebut terutama terhadap dampak yang ditimbulkan merupakan faktor yang memudahkan terjadinya tindakan penyalahgunaan zat narkoba tersebut. Kondisi seperti ini perlu adanya perhatian dan control dari orang-orang terdekat dalam hal ini orang tua dan masyarakat disekitarnya terutama yang saya rekomendasikan pada kegiatan PPM ini adalah terbuka pada orang tua, terutama jika terjadi permasalahan, jangan disembunyikan apalagi dipendam sendiri, atau kepada guru, baik guru di sekolah terutama kepada wali kelas, guru mengaji karena melalui wawancara mengaji pada guru mengaji pada setiap selesai sholat magrib dan selalu melakukan sholat berjamaah di tempat pengajian, atau pada pelatih kick boxing.

2. Budaya masyarakat, budaya mabuk-mabukan dalam hal ini meminumminuman keras di Kota Baubau masih sering terjadi, sampai-sampai ada yang menghadang orang lain ditengah jalan karena tidak sadarkan diri, semua itu sudah diluar control para peminum tersebut, baik dilakukan karena stress, maupun karena merayakan sesuatu, dan dampak lainnya adalah kadang kala menantang orang untuk berkelahi atau bahkan memecahkan botol minumannya di tengah jalan. Hal ini tentunya menjadi penyakit masyarakat yang harus menjadi tujuan sosialisasi agar masyarakat kita tidak tergantung dengan zat-zat tersebut karena hanya merugikan bagi yang mengkonsumsinya. Jadi mereka bisa memprediksi bahwa budaya minumminuman keras dapat menjadi pintu gerbang masuknya narkoba, apalagi dari 22 (dua puluh dua) peserta ada 1 (satu) peserta yang mengaku pernah ditawarkan rokok elektrik oleh teman-temannya di sekolah dan hal tersebut sudah diketahui oleh orang tuanya dan sudah melakukan investigasi disekolahnya dan si anak tersebut sudah berjanji pada gurunya dan orang tuanya untuk tidak mengulangi lagi perbuatan tersebut. 
3. Faktor lingkungan si pemakai zat. Faktor lingkungan tersebut memberikan pengaruh pada remaja dan mencetuskan timbulnya motivasi untuk menyalahgunakan zat. Dengan kata lain, timbulnya masalah penyalahgunaan zat asing yang dimasukkan kedalam tubuh para remaja, dicetuskan oleh adanya interaksi antara pengaruh lingkungan dan kondisi psikologis remaja. Hai ini dikemukakan oleh para remaja Kick Boxing. Di dalam upaya pencegahan, tindakan yang dijalankan dapat diarahkan pada dua sasaran proses menurut saya sebagai pembuat program PPM Pertama, diarahkan pada upaya untuk menghindarkan remaja dari lingkungan yang tidak baik dan diarahkan ke suatu lingkungan yang lebih membantu proses perkembangan jiwa remaja, apakah diberikan kegiatan berupa pembagian tugas yang jelas selama berada di rumah jika berada dilingkungan sekolah, disamping proses belajar mengajar, peserta didik diharapkan diikutkan dalam kegiatan lomba, debat, cerdas cermat, olah raga, seni, penelitian baik tingkat daerah maupun nasional kalau perlu sampai ke tingkat nasional. Dilingkungan pergaulan perlu ada control dari masyarakat dan orang tua karena menurut pengakuan mereka kadangkala mereka lupa waktu pulang karena main game online dirumah yang memiliki jaringan online, sehingga lupa tugas tugas di rumah apalagi waktu sholat. Hal ini perlu ada perhatian masyarakat untuk memperingatkan para remaja kita, apalagi yang orang tuanya sibuk yaitu pergi pagi da nada yang pulang jam 5 sore bahkan jam 8 malam. Kedua adalah membantu remaja dalam mengembangkan dirinya dengan baik dan mencapai tujuan yang diharapkan suatu proses pendampingan kepada si remaja, selain: pengaruh lingkungan pergaulan atau pergaulan di luar selain rumah juga pihak sekolah hendaknya memberikan pesan-pesan moral dan menjelaskan bahaya bahan-bahan tersebut secara baik jika masuk ke dalam tubuh seseorang bahwa bahan-bahan tersebut akan merusak sistem saraf manusia dan membuat ketergantungan serta racunnya akan terakumulasi ke dalam tubuh manusia. Jadi pendampingan diberikan oleh semua pihak walaupun rata-rata mereka belum menggunakan tetapi potensi itu bisa saja terjadi dengan kondisi, kondisi yang ada, yaitu anak-anak kurang mendapat perhatian dari orang tua, atau remaja tersebut salah bergaul. 
Jadi remaja sebenarnya berada dalam 3 (tiga) pengaruh yang sama kuat, yakni sekolah (guru), lingkungan pergaulan dan rumah (orang tua dan keluarga); serta ada 2 buah proses yakni menghindar dari lingkungan luar yang jelek, dan proses dalam diri si remaja untuk mandiri dan menemukan jati dirinya. Dalam rangka membimbing dan mengarahkan perkembangan remaja, tindakan yang harus dan dapat dilakukan adalah:

\section{Sikap dan tingkah laku}

Tujuan dari suatu perkembangan remaja secara umum termasuk kegiatan PPM ini adalah merubah sikap dan tingkah laku para remaja, dari cara yang kekanak-kanakan menjadi cara yang lebih dewasa. Sikap kekanak-kanakan seperti mementingkan diri sendiri (egosentrik), selalu menggantungkan diri pada orang lain, menginginkan pemuasan segera, dan tidak mampu mengontrol perbuatannya, harus diubah menjadi mampu memperhatikan orang lain, berdiri sendiri, menyesuaikan keinginan dengan kenyataan yang ada dan mengontrol perbuatannya sehingga tidak merugikan diri sendiri dan orang lain. Untuk itu dibutuhkan perhatian dan bimbingan dari pihak orang tua. Orang tua harus mampu untuk memberi perhatian, memberikan kesempatan untuk remaja mencoba kemampuannya. Berikan penghargaan dan hindarkan kritik dan celaan, berikan contoh yang baik di keluarga baik dalam bertutur sapa, maupun dalam perbuatan dalam hal ini tidak ada contoh-contoh kekerasan, sehingga anak merasa betah.

\section{Emosional}

Remaja biasanya dalam mendapatkan kebebasan emosional, remaja mencoba merenggangkan hubungan emosionalnya dengan orang tua, oleh karena itu melalui kegiatan PPM ini, para remaja kick boxing harus dilatih dan belajar untuk memilih dan menentukan keputusannya sendiri. Usaha ini biasanya disertai tingkah laku memberontak atau membangkang. Dalam hal ini diharapkan pengertian orang tua untuk tidak melakukan tindakan yang bersifat menindas, akan tetapi berusaha membimbingnya secara bertahap. Jangan menciptakan suasana lingkungan yang lain, yang kadang-kadang menjerumuskannya dalam hal 
ini anak menjadi nakal, pemberontak dan malah mempergunakan narkotika (menyalahgunakan obat).

\section{Mental intelektual}

Dalam perkembangannya mental intelektual melalui kegiatan PPM ini diharapkan remaja kick boxing dapat menerima emosionalnya dengan memahami mengenai kelebihan dan kekurangan dirinya. Dengan begitu ia dapat membedakan antara cita-cita dan angan-angan dengan kenyataan sesungguhnya. Pada mulanya daya pikir remaja banyak dipengaruhi oleh fantasi, sejalan dengan meningkatnya kemampuan berpikir secara abstrak. Pikiran yang abstrak ini seringkali tidak sesuai dengan kenyataan yang ada dan dapat menimbulkan kekecewaan dan keputusasaan. Untuk mengatasi hal ini dibutuhkan bantuan orang tua dalam menumbuhkan pemahaman diri tentang kemampuan yang dimilikinya berdasarkan kemampuan yang dimilikinya tersebut. Jangan membebani remaja dengan berbagai macam harapan dan angan-angan yang kemungkinan sulit untuk dicapai.

\section{Sosial}

Para peserta PPM diperkenalkan bahwa manusia pada hakekatnya merupakan sebagai makhluk sosial oleh karena itu untuk mencapai tujuan perkembangannya, remaja harus belajar bergaul dengan semua orang, baik teman sebaya atau tidak sebaya, maupun yang sejenis atau berlainan jenis. Adanya hambatan dalam hal ini dapat menyebabkan ia memilih satu lingkungan pergaulan saja misalnya suatu kelompok tertentu dan ini dapat menjurus ke tindakan penyalahgunaan zat. Sebagaimana kita ketahui bahwa ciri khas remaja adalah adanya ikatan yang erat dengan kelompoknya. Hal ini menimbulkan ide, bagaimana caranya agar remaja memiliki sifat dan sikap serta rasa citra: disiplin dan loyalitas terhadap teman, orang tua dan cita-citanya. Selain itu juga kita sebagai orang tua dan guru, harus mampu menumbuhkan suatu budi pekerti/akhlaq yang luhur dan mulia, suatu keberanian untuk berbuat yang mulia dan menolong orang lain dan menjadi teladan yang baik.

\section{Pembentukan identitas diri}

Pada kegiatan PPM ini para remaja diperkenalkan proses pengenalan identitas diri, karena akhir daripada suatu perkembangan remaja adalah 
pembentukan identitas diri. Pada saat ini segala norma dan nilai sebelumnya merupakan sesuatu yang datang dari luar dirinya dan harus dipatuhi agar tidak mendapat hukuman, berubah menjadi suatu bagian dari dirinya dan merupakan pegangan atau falsafah hidup yang menjadi pengendali bagi dirinya. Untuk mendapatkan nilai dan norma tersebut diperlukan tokoh identifikasi yang menurut penilaian remaja cukup di dalam kehidupannya. Orang tua memegang peranan penting dalam preoses identifikasi ini, karena mereka dapat membantu remajanya dengan menjelaskan secara lebih mendalam mengenai peranan agama dalam kehidupan dewasa, sehingga penyadaran ini memberikan arti yang baru pada keyakinan agama yang telah diperolehnya. Untuk dapat menjadi tokoh identifikasi, tokoh tersebut harus menjadi kebanggaan bagi remaja. Tokoh yang dibanggakan itu dapat saja berupa orang tua sendiri atau tokoh lain dalam masyarakat, baik yang masih ada maupun yang hanya berasal dari sejarah atau cerita.

\section{KESIMPULAN DAN SARAN}

\section{a. Kesimpulan}

Kesimpulan yang diperoleh dari kegiatan Pengabdian Kepada Masyarakat adalah:

1. Bentuk pembinaan yang diberikan kepada remaja agar tidak menyalahgunakan narkoba adalah: a) dengan merubah sikap dan tingkah laku remaja yang negatif ke sikap yang positif, misalnya yang tadinya tidak rajin sholat tepat pada waktunya diajarkan untuk disiplin yaitu sholat tepat pada waktunya, atau yang membawa kendaraan bermotor yang tidak memiliki sim hendaknya yang sudah cukup umur mengurus sim atau yang belum cukup umur jangan membawa motor; b) dilatih mengendalikan emosionalnya misalnya jangan suka memaki kepada siapa saja; c) usaha penggemblengan mental intelektual dengan melihat segala potensi yang dimiliki dalam hal ini menyangkut kelebihan dan kekurangannya; d) Diajarkan tentang hidup sebagai makhluk sosial dan e) pembentukan identitas diri 
2. Bentuk pendampingan yang dilakukan dalam PPM ini adalah dengan 3 (tiga) pendekatan yaitu: a) orang tua; b) para guru di sekolah termasuk guru mengaji dan c) pelatih kick boxing.

\section{b. Saran}

Adapun saran-saran dari kegiatan pengabdian kepada masyarakat adalah:

1. Pencegahan lebih baik dan lebih murah pada remaja kita agar terhindar dari bahaya narkoba terutama direkomendasikan pada orang tua sebagai yang terdekat dengan anak-anak mereka dan perlu dukungan dari berbagai pihak seperti pihak sekolah, instansi pemerintah, maupun organisasi masyarakat guna menyalurkan aspirasi maupun bakat para remaja kita.

2. Dampak dari penyalahgunaan narkoba tidak hanya mengancam kelangsungan hidup dan masa depan penyalahgunanya saja, namun juga masa depan bangsa dan negara, tanpa membedakan strata sosial, ekonomi, usia maupun tingkat pendidikan. Sampai saat ini tingkat peredaran narkoba sudah merambah pada berbagai level, tidak hanya pada daerah perkotaan saja melainkan sudah menyentuh komunitas pedesaan. Oleh karena itu kita lebih waspada agar anak-anak kita benar-benar dalam pengawasan orang tua, tidak dibiarkan mereka bergaul pada hal-hal yang negatif, seperti kumpul-kumpul dengan kelompoknya sampai larut malam, atau mengikuti balapan motor yang mengganggu para pengendara lain, apalagi sambil merokok.

\section{DAFTAR PUSTAKA}

\section{Buku}

Anwar Nuris. 2013. Remaja dan Penyalahgunaan Narkoba. Majalah Niat. Edisi II. Jakarta.

AR.Sujono dan Bony Daniel. 2011. Komentar dan Pembahasan Undang-Undang Nomor 35 Tahun 2009. Sinar Grafika. Jakarta.

Darmono. 2006. Toksikologi Narkoba dan Alkohol (Pengaruh Neorotoksisitasnya pada Saraf Otak). Penerbit Universitas Indonesia (UI-Press). Jakarta.

Harmawati. 2013. Buku Panduan Pencegahan Pemberantasan Penyalahgunaan Peredaran Gelap Narkoba (P4GN) Bagi Keluarga dan Masyarakat. Badan Narkotika Nasional (BNN) Propinsi Sulawesi Tenggara. Kendari. 
Hong, Tho Lai, dan Ho Peck Leng. 2001. Sains I (Diterjemahkan oleh Purbodiningrat dan Geino U. Purbodiningrat). PT. Aqua Mandiri. Jakarta.

http://www.indopos.co.id/2015/12/peredaran-narkoba-di-baubau-meningkat. Html \#sthash.uOVExyUx.dpuf

Ida Listyarini Handoyo. 2004. Narkoba perlukah Mengenalnya? PT. Pakar Raya. Yogyakarta.

Martono, Lydia Harlina, dan Satya Joewana. 2006. Pencegahan dan Penanggulangan Penylahgunaan Narkoba Berbasis Sekolah. Balai Pustaka (Persero). Jakarta.

Martono, Lydia Harlina, dan Satya Joewana. 2009. Membantu Pemulihan Pecandu Narkoba. Balai Pustaka (Persero). Jakarta. 